\title{
Multi-temporal runoff-sediment discharge relationships
}

\author{
Honglin Xiao ${ }^{1}$, Jinping Zhang ${ }^{1}$, and Hongyuan Fang ${ }^{1}$ \\ ${ }^{1}$ Zhengzhou University
}

January 4, 2022

\begin{abstract}
To understand the runoff-sediment discharge relationship, this study examined the annual runoff and sediment discharge data obtained from the Tangnaihai hydrometric station. The data were decomposed into multiple time scales through Complete Ensemble Empirical Mode Decomposition with adaptive noise (CEEMDAN). Furthermore, double cumulative curves were plotted and the cointegration theory was employed to analyze the microscopic and macroscopic multi-temporal correlations between the runoff and the sediment discharge and their detailed evolution.
\end{abstract}

\section{Multi-temporal runoff-sediment discharge relationships}

Honglin Xiao ${ }^{\mathrm{a}}$, Jinping Zhang ${ }^{\mathrm{a}, \mathrm{b}}, 11^{*}$ Corresponding authors: Name: Jinping Zhang, E-mail address: jinping2000_zh@163.com; Name: Hongyuan Fang, E-mail address: 18337192244@163.com., Hongyuan Fang $\mathrm{a},{ }^{*}$

a: School of Water Conservancy Engineering, Zhengzhou University, High-tech District, No. 100 Science Road, Zhengzhou City, 450001, Henan Province, China.

b: Yellow River Institute for Ecological Protection \& Regional Coordinated Development, Zhengzhou University, Zhengzhou City, 450001, Henan Province, China.

\begin{abstract}
To understand the runoff-sediment discharge relationship in the source region of the Yellow River, this study examined the annual runoff and sediment discharge data obtained from the Tangnaihai hydrometric station. The data were decomposed into multiple time scales through Complete Ensemble Empirical Mode Decomposition with adaptive noise (CEEMDAN). Furthermore, double cumulative curves were plotted and the cointegration theory was employed to analyze the microscopic and macroscopic multi-temporal correlations between the runoff and the sediment discharge and their detailed evolution. Multi-temporal component composite models were then constructed considering structural breaks. The simulation results were compared with the actual values to examine the accuracy of the models. The results suggested that the runoff and the sediment discharge variations in the source region of the Yellow River showed reasonable consistency as a whole. However, their relationship at different time scales varied slightly. The runoff-sediment discharge double cumulative curves in the multi-temporal components exhibited high goodness of fit. The curves of the intrinsic mode function 1 and 2 (IMF1 and IMF2) components provided a more satisfactory goodness of fit, whereas distinct breakpoints were present in those of IMF3 and IMF4. The variations in the runoff-sediment discharge relationship of the raw data series resulted from the different time scales. The medium- and long-term runoff-sediment discharge relationships were insignificant, which affected the raw data series. With the help of the variable structure cointegration composite model, the smallest average relative error for the simulated annual runoff $(7.82 \%)$ was obtained. This composite model could more accurately reflect the long-term equilibrium and short-term fluctuating relationships between the runoff and the sediment discharge in the source region of the Yellow River.
\end{abstract}


Keywords: runoff, sediment discharge, source region of the Yellow River, variable structure cointegration, multi-temporal scales

\section{References}

Adarsh, S., Reddy, M.J., 2018. Multiscale characterization and prediction of monsoon rainfall in India using Hilbert-Huang transform and time-dependent intrinsic correlation analysis. Meteorology and Atmospheric Physics, 130(6), 667-688.

Bai, T., Wei, J., Chang, O., Yang, W.W., Huang, Q., 2019. Optimize multi-objective transformation rules of water-sediment regulation for cascade reservoirs in the Upper Yellow River of China. Journal of Hydrology, 577, Article Number: UNSP 123987.

Bello, M.O., Solarin, S.A., Yen, Y.Y., 2018. The impact of electricity consumption on $\mathrm{CO}_{2}$ emission, carbon footprint, water footprint and ecological footprint: The role of hydropower in an emerging economy. Journal of Environmental Management, 219, 218-230.

Boukhelkhal, A., Bengana, I., 2018. Cointegration and causality among electricity consumption, economic, climatic and environmental factors: Evidence from North -Africa region. Energy, 163, 1193-1206.

Cui, B.L., Li, X.Y., 2011. Coastline change of the Yellow River estuary and its response to the sediment and runoff (1976-2005). Geomorphology, 127(1-2), 32-40.

Colominas, M.A., Schlotthauer, G., Torres, M.E., 2014. Improved complete ensemble EMD: A suitable for biomedical signal processing. Biomedical Signal Processing and Control,14(11), 19-29.

Chang, N.B., Yang, Y.J., Imen, S., Mullon, L., 2017. Multi-scale quantitative precipitation forecasting using nonlinear and nonstationary teleconnection signals and artificial neural network models. Journal of Hydrology, 548, 305-321.

Engle, R.F., Granger, C.W.J., 1987. Cointegration and Error Correction: Representation, Estimation, and Testing. Econometrica, 55,252-276.

Gu, C.J., Mu, X.M., Gao, P., Zhao, G.J., Sun, W.Y., Tan, X.J., 2019. Distinguishing the effects of vegetation restoration on runoff and sediment generation on simulated rainfall on the hillslopes of the loess plateau of China. Plant and Soil, 447 (1-2), 393-412.

Guo, Q.C., Zheng, Z., Huang, L.M., Deng, A.J., 2020a. Regularity of sediment transport and sedimentation during floods in the lower Yellow River, China. International Journal of Sediment Research, 35 (1), 97-104.

Guo, W.X., Li, Y., Wang, H.X., Cha, H.F., 2020b. Temporal variations and influencing factors of river runoff and sediment regimes in the Yangtze River, China. Desalination and Water Treatment, 174, 258-270.

Gao, G.Y., Ma, Y., Fu, B.J., 2016. Multi-temporal scale changes of streamflow and sediment load in a loess hilly watershed of China. Hydrological Processes, 30(3), 365-382.

Gu, A., Zhang, Y., Pan, B.L., 2017. Relationship between Industrial Water Use and Economic Growth in China: Insights from an Environmental Kuznets Curve. Water, 9(8), Article Number: 556.

Gao, F., Tong, M.L., Gao, Y.P., Yang, T.G., Zhao, C.S., 2019. The application of co-integration theory in ensemble pulsar timescale algorithm. Research in Astronomy and Astrophysics, 19(7), Article Number: 100.

Han, J.Q., Gao, J.N., Luo, H., 2019. Changes and implications of the relationship between rainfall, runoff and sediment load in the Wuding River basin on the Chinese Loess Plateau, Catena, 175, 228-235.

Hu, J.F., Zhao, G.J., Mu, X.M., Tian, P., Gao, P., Sun, W.Y., 2019. Quantifying the impacts of human activities on runoff and sediment load changes in a Loess Plateau catchment, China. Journal of Soils and Sediments, 19(11), 3866-3880. 
Heberling, M.T., Nietch, C.T., Thurston, H.W., Elovitz, M., Birkenhauer, K.H., Panguluri, S., Ramakrishnan, B., Heiser, E., Neyer, T., 2015. Comparing drinking water treatment costs to source water protection costs using time series analysis. Water Resources Research, 51(11), 8741-8756.

Jiang, C., Zhang, L.B., Tang, Z.P., 2017. Multi-temporal scale changes of streamflow and sediment discharge in the headwaters of Yellow River and Yangtze River on the Tibetan Plateau, China. Ecological Engineering, $102,240-254$.

Jiang, S.H., Ren, L.L., Yong, B.; Fu, C.B., Yang, X.L., 2012. Analyzing the effects of climate variability and human activities on runoff from the Laohahe basin in northern China. Hydrology Research, 43(1-2), 3-13.

Kuang, C.P., Su, P., Gu, J., Chen, W.J., Zhang, J., Zhang, W.L., Zhang, Y.F., 2014. Multi-Time Scale Analysis of Runoff at the Yangtze Estuary Based on the Morlet Wavelet Transform Method. Journal of Mountain Science, 11(6), 1499-1506.

Kohler M. A., 1949. On the Use of Double-mass analysis for testing the consistency of meteorological records and for making required adjustments. Bull. Ann.Meteol. Soc, 30, 188-189.

Li, E.H., Mu, X.M., Zhao, G.J., Gao, P., Sun, W.Y., 2017. Effects of check dams on runoff and sediment load in a semi-arid river basin of the Yellow River. Stochastic Environmental Research and Risk Assessment, 31, 1791-1803.

Lu, Z.X., Feng, Q., Zou, S.B., Xie, J.L., Yin, Z.L., Li, F., 2020. The heterogeneity of hydrometeorological changes during the period of 1961-2016 in the source region of the Yellow River, China. Sciences in Cold and Arid Regions, 12 (2), 104-118.

Nourani, V., Molajou, A., Tajbakhsh, A.D., Najafi, H., 2019. A Wavelet Based Data Mining Technique for Suspended Sediment Load Modeling. Water Resources Management, 33(5), 1769-1784.

Prasad, R., Deo, R.C., Li, Y., Maraseni, T., 2019. Weekly soil moisture forecasting with multivariate sequential, ensemble empirical mode decomposition and Boruta-random forest hybridizer algorithm approach. Catena, 177,149-166.

Peng, S.Z., Liu, W.X., Wang, W.G., Shao, Q.X., Jiao, X.Y., Yu, Z.B., Xing, W.Q., Xu, J.Z., Zhang, Z.X., Luo, Y.F., 2013. Estimating the Effects of Climatic Variability and Human Activities on Streamflow in the Hutuo River Basin, China. Journal of Hydrologic Engineering, 18(4), 422-430.

Ren, H.R., Li, G.S., Cui, L.L., He, L., 2015. Multi-scale variability of water discharge and sediment load into the Bohai Sea from 1950 to 2011. Journal of Geographical Sciences, 25(1), 85-100.

Singh T., 2015. On the International Trade and Economic Growth Nexus in New Zealand. Economic Papers: A journal of applied economics and policy, 34(1-2), 92-106.

Tanzil, J.T.I., Goodkin, N.F., Sin, T.M., Chen, M.L., Fabbro, G.N., Boyle, E.A., Lee, A.C., Toh, K.B., 2019. Multi-colony coral skeletal Ba/Ca from Singapore's turbid urban reefs: Relationship with contemporaneous in-situ seawater parameters. Geochimica Etcosmochimica Acta, 250, 191-208.

Torres, M.E., Colominas, M.A., Schlotthauer, G., Flandrin, P., 2011. A complete ensemble empirical mode decomposition with adaptive noise. Proc. 36th IEEE Int. Conf. on Acoust, Speech and Signal Process. ICASSP 2011, Prague, Czech Republic, 4144-4147.

Varvani, J., Khaleghi, M.R., Gholami, V., 2019. Investigation of the Relationship between Sediment Graph and Hydrograph of Flood Events (Case Study: Gharachay River Tributaries, Arak, Iran). Water Resources, $46(6), 883-893$.

Vicente G.S., 2014. Assessing the Historical Water Flow Allocation in the Lower Rio Grande between Mexico and the United States. Journal of Borderlands Studies, 29(2), 275-289. 
Yu, M.Z., Xu, X.X., Liu, P.L., Zheng, S.Q., 2012. The response of runoff and sediment on eco-environmental change of Yan'gou watershed in the loess hilly region. Journal of Food Agriculture \& Environment, 10(1), 941-945.

Zhao, X.N., Chen, X.L., Huang, J., Wu, P.T., Helmers, M.J., 2014. Effects of vegetation cover of natural grassland on runoff and sediment yield in loess hilly region of China. Journal of the Science of Food and Agriculture, 94(3), 497-503.

Zhang, Q., Chen, G.Y., Su, B.D., Disse, M., Jiang, T., Xu, C.Y., 2008.Periodicity of sediment load and runoff in the Yangtze River basin and possible impacts of climatic changes and human activities. Hydrological Sciences Journal-Journal Des Sciences Hydrologiques, 53(2), 457-465.

Zhang, Q., Xu, C.Y., Becker, S., Jiang, T., 2006. Sediment and runoff changes in the Yangtze River basin during past 50 years. Journal of Hydrology, 331(3-4), 511-523.

Zhang, J.P., Xiao, H.L., Zhang, X., Li, F.W., 2019a. Impact of reservoir operation on runoff and sediment load at multi-time scales based on entropy theory. Journal of Hydrology, 569, 809-815.

Zhang, J.P., Ding, Z.H., You, J.J., 2014. The joint probability distribution of runoff and sediment and its change characteristics with multi-time scales, Journal of Hydrology and Hydromechanics, 62(3), 218-225.

Zhang, J.P., Yuan, W.L., Guo, B.T., 2013. Study on prediction of stream flow based on cointegration theory. Water Resources and Power, 31(5), 18-20, 99.

Zhang, X.F., Yan, H.C., Yue, Y., Xu, Q.X., 2019b. Quantifying natural and anthropogenic impacts on runoff and sediment load: An investigation on the middle and lower reaches of the Jinsha River Basin. Journal of Hydrology-Regional Studies, 25, Article Number: UNSP 100617.

Zhang, L., Karthikeyan, R.; Bai, Z.; Wang, J., 2017. Spatial and temporal variability of temperature, precipitation, and streamflow in upper Sang-kan basin, China. Hydrological Processes, 31(2), 279-295. 


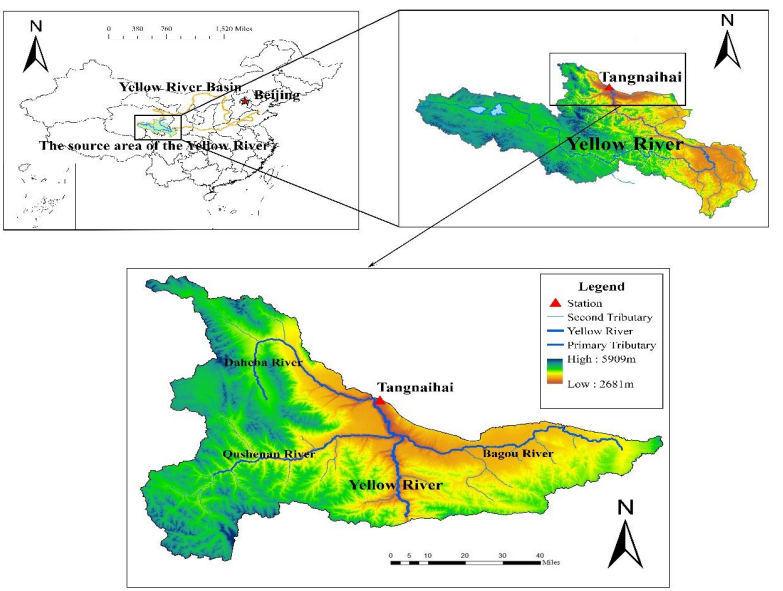

Figure 1 Location of the study area with the Tangnaihai station

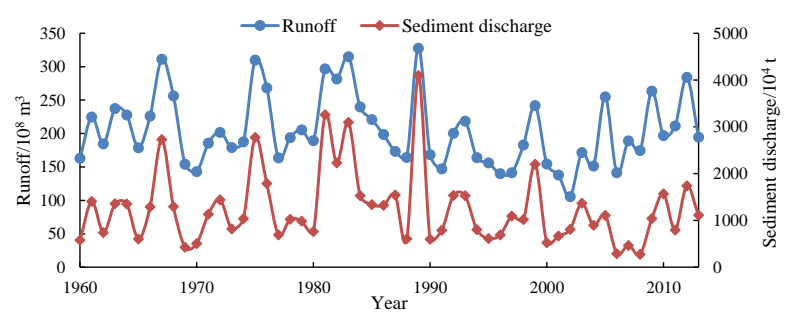

Figure 2 Variation in the runoff and sediment discharge series observed at the

Tangnaihai station 